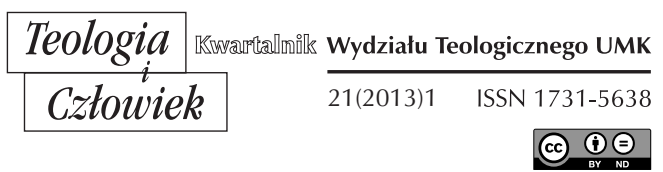

KS. TADEUSZ ZADYKOWICZ*

LUBLIN

\title{
NAUCZANIE MORALNE KOŚCIOŁA W DIALOGU ZE WSPÓŁCZESNĄ KULTURĄ ZAWARTE W JEGO NOWYM KATECHIZMIE
}

DOI: http://dx.doi.org/10.12775/TiCz.2013.002

Kościół, wypełniając swoją funkcję nauczycielską, zwraca się zawsze do konkretnego człowieka, do ludzi swoich czasów. W wypełnianiu tej misji od dawna dużą rolę odgrywały katechizmy. W nich bowiem zawierała się jasna i wyczerpująca prezentacja treści wiary, wyrażona w języku zrozumiałym dla ludzi danej epoki i kultury ${ }^{1}$. Taką rolę miał też spełnić Katechizm ogłoszony mocą Konstytucji apostolskiej Fidei depositum w dniu 11 października 1992 r. przez Jana Pawła II. O wadze, jaką sam Papież przywiązywał do jego publikacji, świadczą słowa, według których jest to wydarzenie o „nieporównywalnym znaczeniu i bogactwie" ${ }^{\prime 2}$. Jest rzeczą oczywistą, że to znaczenie i bogactwo nie wynika z samej treści

* Ks. dr hab. Tadeusz Zadykowicz jest adiunktem w Katedrze Teologii Moralnej Ogólnej Instytutu Teologii Moralnej Katolickiego Uniwersytetu Lubelskiego Jana Pawła II.

${ }^{1}$ Por. Jan Paweł II, Adhortacja apostolska Catechesi tradendae, nr 50; tenże, List do biskupów niemieckich z okazji 400-lecia śmierci św. Piotra Kanizego (19.09.1997), nr 4. Por. także: F. Greniuk, Katechizm dla Kościoła i świata, w: Katechizm Kościoła Katolickiego. Przestanie moralne Kościoła, red. J. Nagórny, A. Derdziuk, Lublin 1995, s. 15.

${ }^{2}$ Jan Paweł II, Konstytucja apostolska Fidei depositum. 
głoszonej wiary, która przecież pozostaje niezmienna. O wiele bardziej tę doniosłość należy wiązać z sytuacją, w jakiej przyszło współczesnemu Kościołowi podjąć inicjatywę opracowania kompendium całej nauki katolickiej w dziedzinie wiary i moralności. Sytuacja ta naznaczona jest pewnymi zjawiskami społecznymi i kulturowymi, w których nastąpiło pomieszanie pojęć, zatarcie wrażliwości moralnej, czy wręcz chaos moralny. Wobec takich wyzwań Katechizm miał za zadanie przypomnieć autentyczną naukę Kościoła, opartą na Piśmie Świętym i Tradycji. Jeżeli jednak jego nauczanie miało skutecznie służyć ożywieniu wiary i życia religijnego oraz zaowocować postawami w życiu moralnym, musiało wejść $\mathrm{w}$ dialog z człowiekiem, który do odpowiedzi na dar samoudzielającego się Boga jest wezwany w konkretnych uwarunkowaniach kulturowych. Dlatego można mówić zarówno o pewnych nova, jak i vetera w Katechizmie. Vetera związane są nade wszystko z samą treścią wiary. Natomiast novum wynika ze sposobu jej komunikowania i wiąże się z koniecznością poszukiwania języka, który będzie zrozumiały dla współczesnego człowieka, przeżywającego swoje „nowe” problemy i szukającego ich rozwiązania ${ }^{3}$. W niniejszym opracowaniu chodzi o zwrócenie uwagi na owe nova et vetera nade wszystko w nauczaniu moralnym, zawartym w III części Katechizmu ${ }^{4}$. Nie sposób oczywiście w krótkim tekście dokonać szczegółowej klasyfikacji zagadnień katechizmowych według schematu stare-nowe. Da się natomiast i - jak się wydaje - warto wskazać na wyraźne bądź tylko domyślne podstawy kulturowe nauczania na temat życia moralnego jako życia w relacji do Boga oraz do człowieka i świata.

${ }^{3}$ Wydaje się, że uwzględnieniu tych nowych elementów miały służyć szerokie konsultacje, jakim poddano wstępny projekt Katechizmu, rozsyłając go do wszystkich biskupów, uniwersytetów katolickich, akademii i wydziałów teologicznych oraz różnych instytucji kościelnych. Dbałość o jak najbardziej właściwe, dostosowane do współczesności, przedstawienie prawd, stała również u podstaw poprawek, jakie wprowadzono przed publikacją tekstu typicznego. Zwraca na to uwagę Jan Paweł II w Liście Laetamur magnopere (15.08.1997). Por. także: Jan Paweł II, List do kapłanów na Wielki Czwartek 1993 r. Dar kaptaństwa a nowy Katechizm (8.04.1993); tenże, Kat. Katecheza przekazem objawionego Stowa Bożego (9.01.1985), nr 2.

${ }^{4} \mathrm{~W}$ odniesieniu do kwestii ochrony życia tradycyjne oraz oryginalne ujęcia w Katechizmie omawia J. Wróbel, Nova et vetera w piątym przykazaniu Dekalogu, w: Katechizm Kościoła Katolickiego. Przestanie moralne Kościoła, s. 157-168. 


\section{NOVA ET VETERA W KATECHIZMIE KOŚCIOŁA KATOLICKIEGO}

W Konstytucji Fidei depositum Jan Paweł II zaznacza, że Katechizm zawiera rzeczy stare i nowe, ponieważ - jak tłumaczy - wiara pozostaje zawsze ta sama, a zarazem jest źródłem wciąż nowego światła. Tym uzasadnia Papież wybór dawnego, tradycyjnego układu Katechizmu, stosowanego już wcześniej, ujmującego treść w czterech częściach: wyznanie wiary, liturgia, zasady chrześcijańskiego postępowania oraz modlitwa ${ }^{5}$. Również schemat części III, poświęconej moralności, ma charakter tradycyjny i został w znacznej mierze oparty o przykazania Dekalogu. Ten układ preceptywny jest jednym z najstarszych sposobów ujmowania całości życia moralnego ${ }^{6}$. Jednakże zarówno część III, jak i cały Katechizm zostaje poniekąd ujęta w nowy sposób, co uzasadnia Papież koniecznością dawania odpowiedzi na pytania stawiane przez naszą epokę. Nowość tego ujęcia polega nade wszystko na ścisłym powiązaniu Dekalogu z przykazaniem miłości oraz wpisaniu go w nowy kontekst - kontekst Nowego Przymierza. To sprawia, że moralność prezentowana przez Katechizm nie ma charakteru legalistycznego ani minimalistycznego, cechującego teologię moralną potrydencką, ale jednocześnie zachowuje wierność wobec tradycji. To na ten tradycyjny schemat Dekalogu zostaje nałożone całe bogactwo aktualnych problemów z ich złożonością. Pod klasycznymi tytułami poszczególnych przykazań kryje się zatem nie tylko „stara" problematyka teologicznomoralna, ale także nowe zagadnienia i akcenty, jakie przyniosły współczesne nam czasy ${ }^{7}$.

Wybór Dekalogu jako zrębu szczegółowej moralności chrześcijańskiej jest - zdaniem Rosika - spowodowany tym, że duchowy klimat współczesnego świata, sytuacja neopogańskiego nastawienia, doprowadziły do tego, że problem Dziesięciu Przykazań pokrywa się milczeniem8. Daje się zauważyć względem niego niechęć lub co najmniej obojętność.

${ }^{5}$ Taki układ strukturalny wzorowany jest nade wszystko na Katechizmie rzymskim opublikowanym w 1566 roku po Soborze Trydenckim.

6 Por. S. Raponi, Decalogo e la vita cristiana, "Studia Moralia” 32 (1994) nr 1, s. $93-103$.

7 Por. Wróbel, Nova et vetera w piątym przykazaniu Dekalogu, s. 157; M. Vidal, La matriz tomista de la moral general en el Catecismo de la Iglesia Catolica, "Studia Moralia" 32 (1994) nr 1, s. 21.

${ }^{8}$ Por. S. Rosik, Podstawowe punkty wyjścia rozważań nad Katechizmem Kościoła Katolickiego w jego warstwie aksjologiczno-deontologicznej, w: Katechizm Kościota Katolickiego. Przestanie moralne Kościota, s. 134. 
Dlatego być może to właśnie ten schemat wybrano, by Dekalog ukazać na nowo jako Słowo Boga, zawierające podstawowe wartości i drogowskazy niezbędne człowiekowi szukającemu prawdziwego sensu życia i ocalenia swej wolności. Dekalog - w opinii redaktorów Katechizmu - jest więc ciągle aktualny i powinien być na nowo odkrywany; także w dzisiejszym świecie i przez współczesnego człowieka, często przewrażliwionego na punkcie swojej wolności, którą prawo, przykazania zdają się mu odbierać. Ta swoista „alergia” wobec nakazów i zakazów powoduje, że należy na nowo wniknąć w moralne przesłanie Dekalogu i przekazać go w taki sposób, aby - mimo jego historycznie uwarunkowanego sformułowania - ujawnił się jego sens uniwersalny, a więc sens, który ułatwia i pomaga ludziom wszystkich czasów i kultur podejmować konkretne decyzje moralne ${ }^{9}$. Wydaje się więc, że już sam wybór Dekalogu jako schematu wykładu treści moralnych jest odpowiedzią na współczesne pokusy całkowitej autonomii, uwolnienia się od jakiegokolwiek autorytetu zewnętrznego, co doprowadziło dzisiejsze społeczeństwa do postaw permisywnych, relatywistycznych, czy wręcz libertyńskich. Z drugiej jednak strony istnieją we współczesnych społeczeństwach także silne tendencje do ujmowania wszystkiego w normy prawne. Ludzie zdają więc sobie sprawę z potrzeby pewnych uregulowań prawnych, które zabezpieczają elementarną wolność. Tego typu świadomość może również stanowić pewien punkt wyjścia dla zrozumienia moralności chrześcijańskiej jako moralności przykazań.

Kulturowo uwarunkowany charakter nauczania moralnego zawartego w Katechizmie Kościoła Katolickiego można dostrzec zarówno w celach, jak i sposobach przedstawiania depozytu nauki chrześcijańskiej. Cel, jaki przyświeca redaktorom, związany jest nade wszystko z jak najbardziej przystępną prezentacją swego nauczania. Taki cel nie mógłby być osiągnięty bez uwzględnienia specyfiki uwarunkowań życiowych adresatów. Nie ulega wątpliwości - o czym zresztą pisze Jan Paweł II w Konstytucji Fidei depositum - że celem Katechizmu była również odnowa katolickiego nauczania w duchu Soboru Watykańskiego II. Co więcej, nie chodziło tylko o odnowę samego nauczania, ale także o odnowę całego życia Kościoła, w tym również o odnowę moralną. Jeśli wziąć pod uwagę, że ów duch Soboru wyrażał się między innymi w aggiornamento i oznaczał całość zabiegów mających na celu przystosowanie niezmiennego w zasadniczych

9 Por. tamże, s. 138. 
punktach depozytu wiary do zmieniających się warunków historycznych i społecznych, tak by można było skuteczniej głosić w dzisiejszym świecie naukę Jezusa Chrystusa, to trudno sobie wyobrazić, by to "dostosowanie" do aktualnych potrzeb mogło pominąć dziedzinę życia moralnego. Cel Katechizmu jest więc wyraźnie ewangelizacyjny ${ }^{10}$. Kościół wezwany do ewangelizacji potrzebuje nie tylko jasnej świadomości swojej doktryny, ale także odpowiednich narzędzi, by tę doktrynę głosić. Nowe problemy społeczne, kulturowe, polityczne i moralne stanowią wyzwanie dla Kościoła i domagają się od niego zabrania głosu. Czas, w jakim Kościół katolicki wydał i zaprezentował swój Katechizm, jest - jak pisze Rosik czasem szczególnym ${ }^{11}$. Jest to czas nasilenia się procesów sekularyzacyjnych, wzmagającej się ateizacji, propagowania relatywizmu poznawczego i moralnego. $\mathrm{W}$ tym kontekście można powiedzieć, że Katechizm miał być swoistym remedium na współczesną sytuację. Odpowiedzialność na głoszenie zbawczego orędzia Chrystusa stanęła u podstaw wysiłków na rzecz nowego opracowania swoistego kompendium prawd wiary. Opracowanie to $\mathrm{w}$ zamierzeniu miało służyć głębszemu poznaniu prawd wiary oraz pogłębieniu więzi z Chrystusem przez konkretnego człowieka, żyjącego w ściśle określonych uwarunkowaniach. Aby te zamierzenia mogły się ziścić, należało dobrze zanalizować warunki życia tegoż człowieka, poznać jego sposób myślenia oraz język, którym się na co dzień posługuje. Te warunki nie są jednak jednolite dla całego świata. To też uzasadnia powstawanie katechizmów w różnych Kościołach lokalnych. Dlatego celem Katechizmu Kościoła Katolickiego nie było dążenie do wyeliminowania katechizmów już istniejących. Przeciwnie, miał on stać się punktem odniesienia dla katechizmów i kompendiów przygotowywanych w różnych krajach oraz "tekstem wzorcowym dla katechezy odnowionej u żywych źródeł wiary"12. W opinii Papieża winien stać się on również zachętą i pomocą do opracowania nowych katechizmów lokalnych, przystosowanych do różnorakich środowisk i kultur, a jednocześnie dbających o zachowanie jedności wiary oraz wierności nauce katolickiej.

${ }^{10}$ Por. S. Łabendowicz, Przedmowa, w: Wyznawać wiare dzisiaj. Katecheza dla dorostych na podstawie Katechizmu Kościoła Katolickiego, Sandomierz 1999, s. 17.

${ }^{11}$ Por. Rosik, Podstawowe punkty wyjścia rozważań nad Katechizmem Kościoła Katolickiego w jego warstwie aksjologiczno-deontologicznej, s. 131.

${ }^{12}$ Jan Paweł II, Konstytucja apostolska Fidei depositum. 
Jeśli zaś chodzi o sposoby głoszenia prawd wiary, to Katechizm nie tyle potępia błędy epoki, ile chce jasno ukazać pociągające piękno nauki wiary i nauki moralnej. W tym celu stara się dowartościować obecność Pisma Świętego i Tradycji oraz ściśle wiąże doktrynę z liturgią. W centrum całego nauczania stawia osobę Jezusa Chrystusa, który dla moralności stanowi źródło, wzór i cel. Nie ma więc on, jak to bywało w przeszłości, charakteru polemicznego i wyłącznie apologetycznego. Ukazywanie wyłącznie negatywnych aspektów omawianych zagadnień zostało zastąpione pozytywną, całościową prezentacją prawd wiary i zagadnień moralnych. Nie oznacza to wszakże skoncentrowania się na samych zasadach z pominięciem życiowych realiów. Redaktorzy Katechizmu zdają sobie sprawę, że kierują to dzieło do człowieka, na którego oddziałują różnorakie prądy kulturowe, nie zawsze sprzyjające wierze i życiu z wiary. Mówił o tym kard. Ratzinger podczas prezentacji Katechizmu: „W świecie nacechowanym przez subiektywizm i wielość punktów widzenia, w którym rzeczywistości takie jak Bóg, Chrystus, Kościól, człowiek, zdają się tracić sens i znaczenie, $\mathrm{z}$ wielu stron można usłyszeć wołanie docierające na różne sposoby, o takie głoszenie prawdy, które ocali człowieka i jego świat, będzie źródłem nadziei na krętej ścieżce ludzkiej historii i ostoją w czasach, gdy znikają ludzkie pewniki"13.

Specyficzną cechą Katechizmu, w tym także jego III części, jest - obok chrystocentryzmu - charakter eklezjalny. Jest to cecha o tyle ważna, że w wielu krajach zarysowały się tendencje zagrażające jedności nauczania Kościoła w kwestiach moralnych. Takim tendencjom, jak się wydaje, miało wyjść naprzeciw ujednolicone kompendium, które w wielu miejscach wskazuje, że życie chrześcijańskie może wzrastać, rozwijać i udzielać się jedynie we wspólnocie eklezjalnej. To w niej każdy chrześcijanin wypełnia swoje powołanie. W niej otrzymuje szereg wskazań w dziedzinie moralności, ale również - poprzez swoje życie moralne - przyczynia się do wzrastania i uświęcania tej wspólnoty. Choć pierwszym adresatem Katechizmu jest Kościół, to zwraca się on także do wszystkich ludzi dobrej woli. Zostaje ofiarowany wszystkim wiernym, którzy pragną bardziej poznać niewyczerpane bogactwo zbawienia (por. Ef 3,8), ale ma też wspierać dążenia ekumeniczne, a także służyć jako źródło poznania wiary Kościoła katolickiego przez tych, którzy jeszcze

${ }^{13}$ J. Ratzinger, Przemówienie wygłoszone podczas konferencji prasowej w watykańskiej Sala Stampa Wykład nauki chrześcijańskiej dla wspótczesnego człowieka, „L'Osservatore Romano" 13 (1992) nr 10, s. 36. 
tej wiary nie podzielają, a niekiedy domagają się uzasadnienia nadziei, która jest $\mathrm{w}$ nas (por. 1P 3,15) ${ }^{14}$.

Można więc powiedzieć, że „nowe” jest w Katechizmie to, co wynika z postępu współczesnej wiedzy o człowieku i techniki oraz przemian społeczno-ekonomicznych, które stawiają przed człowiekiem - a więc i przed Kościołem - nowe wyzwania ${ }^{15}$. Te „nowe” wyzwania Kościół próbuje prześwietlić „starą" prawdą Dekalogu. Jak to już bowiem wynika z Pisma Świętego, wezwania moralne, jakie Bóg kieruje ku człowiekowi, nie odnoszą się do jakiegoś człowieka „idealnego”, ale są skierowane do człowieka konkretnego, żyjącego w określonych okolicznościach czasu i miejsca. Bóg powołuje człowieka „po imieniu”, a więc z uwzględnieniem jego jedyności i niepowtarzalności ${ }^{16}$, przy czym ta jedyność i niepowtarzalność określona jest nie tylko przez osobiste zdolności i talenty, ale także przez okoliczności zewnętrzne.

Katechizm - w zamierzeniu redaktorów - ma stanowić wykład „zdrowej" doktryny i ma być dostosowany do życia dzisiejszych chrześcijan. Śmiało podejmuje więc on zagadnienia, co do których potoczne opinie są odmienne. Proponuje konkretne rozwiązania, które nie zawsze spotkają się z aplauzem. Wchodzi on też $\mathrm{w}$ konkretne sprawy życia codziennego, których ocena nastręcza wielu trudności. Nie jest więc abstrakcyjny, zawieszony w próżni. Przeciwnie, mówi o konkretnych sprawach i stara się być bliski aktualnej rzeczywistości, w jakiej przyszło żyć ludziom dzisiejszych czasów ${ }^{17}$. Wprawdzie nie poświęca on opisowi sytuacji odrębnej części, jednakże liczne nawiązania do tej sytuacji nie pozostawiają wątpliwości. Stosownie do preceptywnego układu III części można wskazać na dwie płaszczyzny życia chrześcijańskiego: odniesienie do Boga oraz życie we wspólnocie międzyludzkiej. Z całą świadomością przenikania się tych płaszczyzn można zauważyć ową charakterystyczną cechę nauczania, jaką jest uwzględnianie uwarunkowań kulturowych.

${ }^{14}$ Por. K. Kupiec, Ekumeniczny wymiar Katechizmu Kościoła Katolickiego, w: Katechizm Kościoła Katolickiego. Wprowadzenie, red. M. Rusecki, E. Pudełko, Lublin 1995, s. 253.

${ }_{15}$ Por. A. Szostek, Etyka otwarta na Ewangelię, w: Katechizm Kościoła Katolickiego. Wprowadzenie, s. 173; B.V. Johnstone, Personalist morality for a technological age: The Catechism of the Catholic Church and Veritatis splendor, "Studia Moralia" 32 (1994) nr 1, s. 121.

${ }^{16}$ Por. J. Nagórny, Moralność chrześcijańska. Życie z Chrystusem i w Chrystusie we wspólnocie Kościoła, w: Katechizm Kościota Katolickiego. Wprowadzenie, s. 178.

${ }^{17}$ Por. Greniuk, Katechizm dla Kościota i świata, s. 33-34. 


\section{KULTUROWE UWARUNKOWANIA ŻYCIA RELIGIJNEGO}

Katechizm Kościoła Katolickiego - jak już wspomniano - oddaje ducha Soboru Watykańskiego II, który przypomniał konieczność „poznawania i rozumienia świata, w którym żyjemy, a także jego nieraz dramatycznych oczekiwań, dążeń i właściwości"18. Dlatego wielokrotnie - explicite i implicite - wyraża swój stosunek do współczesnych religii, nauk, filozofii, systemów politycznych ${ }^{19}$. Wyraża także swój stosunek do współczesnej kultury, która jest skutkiem działania osobowego człowieka, a zarazem tworzy kontekst jego życia. Nie ulega wątpliwości, że rozważania Katechizmu na temat życia moralnego, także w jego kontekście religijnym, zostały wkomponowane i ściśle powiązane $\mathrm{z}$ realiami historycznymi współczesnej epoki. Nauczanie to zatem nie jest zawieszone w próżni, ale odnosi się do realiów życia człowieka dzisiejszych czasów. Rzeczywistość współczesnego świata pełna jest sprzeczności. Da się w niej zauważyć wiele aspektów pozytywnych, ale też wiele zjawisk, które muszą budzić niepokój. Jedne $\mathrm{z}$ nich mogą być powodem optymizmu, a nawet entuzjazmu, inne zaś stają się źródłem utraty nadziei. Wyjątkowe tempo głębokich przemian społecznych i kulturowych sprawia, że prawdy uznawane jeszcze wczoraj za oczywiste i niekwestionowane jawią się dziś jako kontrowersyjne ${ }^{20}$. To zaś, co dawniej było uznawane za niegodne człowieka, dziś staje się normą.

Już pierwszy punkt III części Katechizmu zdaje się odpowiadać współczesnemu poszukiwaniu godności człowieka, jej podstaw oraz dróg urzeczywistniania. Podczas gdy świat stopniuje tę godność i ją relatywizuje, Katechizm wskazuje na jej najgłębsze źródło, jakim jest uczestnictwo w Bożej naturze ${ }^{21}$. Uczestnictwo to winno być jednocześnie źródłem ludzkiego postępowania. Trudno oprzeć się wrażeniu, że to wezwanie do życia na miarę otrzymanej godności jest jakimś rodzajem sprzeciwu wobec takich wizji życia moralnego, które wiązałyby je wyłącznie z posłuszeństwem Bożemu czy ludzkiemu prawu. Podkreślenie

18 Por. KDK, nr 4.

19 Por. J. Szymik, Chrześcijaństwo otwarte, w: Katechizm Kościoła Katolickiego. Wprowadzenie, s. 246.

20 Por. J. Życiński, Świadkowie wolności i prawdy, w: W Duchu i Prawdzie. Katechizm Kościoła Katolickiego w refleksji i życiu, Tarnów 1997, s. 9.

${ }^{21}$ Por. KKK, nr 1691; B. Hidber, Der Mensch als Sünder, „Studia Moralia” 32 (1994) nr 1, s. 76-77. 
elementu łaski, która stoi u źródeł życia moralnego, jest być może także reakcją na wszelkie próby „naturalizowania” moralności, które współcześnie znalazły wyraz w hasłach samorealizacji i samourzeczywistniania.

Wydaje się, że jednym z podstawowych zjawisk współczesności, do których odnosi się Katechizm jest poszukiwanie sensu życia, pragnienie osiągnięcia celu oraz dążenie do szczęścia. W dzisiejszym świecie to pragnienie jest nie zawsze właściwie ukierunkowane. Podobnie nie zawsze właściwie ukierunkowane pozostaje poczucie wielkości człowieka. Katechizm, potwierdzając tę wielkość, wskazuje jednocześnie na jej podstawy oraz zobowiązujący charakter. Podkreśla, że tym, co stanowi o wielkości człowieka, jest łaska Boga oraz dary i charyzmaty Ducha Świętego. One też odpowiadają na najgłębsze tęsknoty osoby. Jest to zatem odpowiedź na pewne nawyki myślowe współczesnej cywilizacji, które zamykają człowieka w jego ograniczonych możliwościach wynikających z kondycji biologicznej oraz całkowitego podporządkowania determinizmom kulturowym. Wbrew temu, człowiek Katechizmu to ktoś, kto nie podlega bez reszty koniecznościom przyrodniczym i kulturowym, ale nade wszystko ktoś, kto jest osobą, a więc zarówno posiada pewne cechy stałe, ale także cechuje go dynamizm² ${ }^{22}$ Podkreślając zaś duchowo-cielesną jedność człowieka oraz jego otwartość na transcendencję, nauczanie Katechizmu zwraca się przeciwko wszelkim fragmentaryzmom w ujęciu ludzkiej natury. Takim fragmentaryzmem jest między innymi ujęcie człowieka jako indywiduum z jednoczesnym pominięciem całego wymiaru społecznego. To charakterystyczne dla skrajnego liberalizmu podejście zostaje wyraźnie odrzucone przez dowartościowanie aspektów wspólnotowych - co ciekawe - także życia religijnego i relacji do Boga.

Pisząc Katechizm, jego redaktorzy musieli mieć świadomość charakteru adresata tego dzieła. Tym adresatem - jak już wspomniano - jest zasadniczo Kościół, ale jest nim również świat, który w dużej mierze jest „światem bez Boga”. Temu światu Kościół, poprzez nauczanie Katechizmu, głosi Boga jako Ojca, który przyszedł w swoim Synu, uczynił nas dziećmi Bożymi, a między sobą braćmi i siostrami ${ }^{23}$. W tym świecie specyficzne zadanie do wypełnienia mają ludzie wierzący. Ich życie mo-

${ }^{22}$ Por. E. Wolicka, Człowiek otwarty na transcendencję, w: Katechizm Kościoła Katolickiego. Wprowadzenie, s. 12.

${ }^{23}$ Por. S. Nowosad, Wspólnotowy wymiar życia chrześcijańskiego, w: Katechizm Kościoła Katolickiego. Przestanie moralne Kościoła, s. 63-64; N. Filippi, La "Vita in Christo" nel Catechismo della Chiesa Cattolica, „Studia Moralia” 32 (1994) nr 1, s. 7. 
ralne winno stać się świadectwem ścisłego zjednoczenia z Chrystusem. Podkreślenie wspólnoty człowieka wierzącego z Chrystusem stoi w opozycji do wizji moralności skoncentrowanych na samej osobie działającej. Jednocześnie Katechizm zdaje się odpowiadać obecnemu także we współczesnym świecie poszukiwaniu Boga, które jest znakiem „otwartości” na Niego. Wydaje się, że nie przypadkowo redaktorzy podkreślają eklezjalny charakter egzystencji chrześcijanina. W dobie znacznego dystansu do Kościoła akcentują, że „to w Kościele, we wspólnocie ze wszystkimi ochrzczonymi, chrześcijanin realizuje własne powołanie"24. Kościół bowiem jest nieodzowną pomocą $\mathrm{w}$ życiu moralnym chrześcijanina jako Matka i Nauczycielka.

Cechą współczesnej kultury jest oddzielenie wiary od moralności oraz moralności od kultu. Wbrew temu Katechizm podkreśla, że „życie moralne jest kultem duchowym"25. Przez nie chrześcijanin oddaje cześć Bogu, a zarazem wyznaje swoją wiarę. Podkreśla również personalistyczne aspekty sakramentalnego charakteru moralności chrześcijańskiej. W takim ujęciu sakramenty są traktowane jako osobowe spotkania z Chrystusem $^{26}$, które niosą osobowe wezwania do przyjęcia Bożego powołania. Nie są więc one - jak się niekiedy uważa - jedynie bezosobowymi znakami czy też „środkiem” i pomocą do zachowania prawa moralnego. Będąc źródłami łaski, uzdalniają one chrześcijanina do współpracy w dziele zbawienia i do budowania Kościoła ${ }^{27}$. Podkreślając rolę sakramentów i charyzmatów, Katechizm przypomina o nadprzyrodzonych źródłach i celach moralności chrześcijańskiej. Moralność ta wynika z daru Boga, jej zaś celem jest osiągnięcie „miasta świętego, niebieskiego Jeruzalem”. Wiedzie ona zatem ku celowi ostatecznemu, którym jest Bóg ${ }^{28}$. Jest ona niczym innym, jak adekwatną odpowiedzią człowieka na bezinteresowne, a więc podyktowane tylko i wyłącznie przez miłość zbawczą, zaangażowanie się Boga w historię człowieka. Tak ukazywana istota moralności musi być odniesiona do wszelkich tendencji, które - niekiedy wychodząc z Dekalogu - sprowadzają ją do zwykłego posłuszeństwa i nadają jej charakter negatywny i minimalistyczny.

\footnotetext{
24 KKK, nr 2030.

25 Tamże, nr 2031.

26 Por. tamże, nr 1088.

27 Por. tamże, nr 2003.

28 Por. tamże, nr 1878.
} 
Styl nauczania Katechizmu na temat moralności chrześcijańskiej jest - jak się wydaje - odpowiedzią na współczesne silne tendencje do zdominowania refleksji etycznej i teologicznomoralnej przez idealizm i racjonalizm, a w konsekwencji przez immanentyzm i subiektywizm ${ }^{29}$. Istota moralności, jak ją przedstawia Katechizm, różni się zasadniczo od nominalistycznie rozumianego woluntaryzmu, czy też pozytywizmu teonomicznego. Wizja moralności zaprezentowana w Katechizmie jest głęboko osadzona w Piśmie Świętym, co nie oznacza lekceważenia porządku naturalnego. Ukazanie tego życia jako „życia w Chrystusie”, a zarazem jako zaangażowania ludzkiej wolności, wydaje się być reakcją na dwa zasadnicze błędy w podejściu do moralności chrześcijańskiej: naturalizmu oraz supernaturalizmu ${ }^{30}$. Zarówno bowiem zakwestionowanie laski, jak i zakwestionowanie wolności człowieka, określają współczesne podejście do samej istoty moralności.

Nawiązania do obecnej sytuacji są widoczne również w interpretacji poszczególnych przykazań Dekalogu. Katechizm, oprócz prezentacji samej ich treści, przywołuje też pewne zjawiska charakterystyczne dla naszych czasów. Widać to chociażby w części prezentującej grzechy sprzeciwiające się kultowi. Obok różnych form idolatrii zostają wyliczone także takie postawy, jak: kult władzy, pieniądza, przyjemności, rasy, przodków czy państwa. Trudno oprzeć się wrażeniu, że tego typu negatywna ocena ma związek z szerzącymi się formami nowej religijności, zwłaszcza w postaci New Age ${ }^{31}$. Również zwrócenie uwagi na zjawisko ateizmu i agnostycyzmu zdaje się odnosić do postaw wielu ludzi we współczesności. Postawy te mają swoje źródło w niektórych ruchach i nurtach kulturowych, których wspólną cechą jest żądanie autonomii, która prowadzi aż do odrzucenia wszelkiej zależności od Boga. Taka fałszywa autonomia prowadzi również do nieuszanowania imienia Bożego oraz Dnia Pańskiego. Wskazując na konkretne formy tych wykroczeń, Katechizm zdaje się pośrednio odnosić do współczesnych zjawisk, które te wykroczenia ukształtowały.

${ }^{29}$ Por. J. Wróbel, Dekalog - Prawo Miłości, w: Katechizm Kościoła Katolickiego. Przestanie moralne Kościoła, s. 81.

${ }^{30}$ Por. J. Nagórny, Moralność chrześcijańska w świetle Katechizmu Kościoła Katolickiego, w: Wyznawać wiarę dzisiaj, s. 439.

${ }^{31}$ Por. A. Derdziuk, Będziesz mitowat Pana Boga swego... I tablica Dekalogu, w: Katechizm Kościoła Katolickiego. Przestanie moralne Kościoła, s. 103. 


\section{KULTUROWY KONTEKST NAUCZANIA NA TEMAT WSPÓLNOTY MIĘDZYLUDZKIEJ}

Także interpretacja przykazań z tzw. drugiej tablicy Dekalogu odnosi się do współczesnych zjawisk, wśród których czołowe miejsce zajmują różnego rodzaju konflikty. Okazało się bowiem, że wprowadzenie pluralizmu i demokratycznych zasad życia społeczno-politycznego nie wystarczyło dla rzeczywistej przemiany oblicza świata ${ }^{32}$. Współczesne konflikty nie dotyczą już tylko relacji między klasami, grupami czy nawet państwami, ale całych cywilizacji. Wydaje się, że owe konflikty wyrastają na bazie skrajnie indywidualistycznego postrzegania człowieka, a więc na określonej antropologii. Niezdolność do wspólnoty, do prawdziwego braterstwa jest niewątpliwie powodem, dla którego Katechizm tak mocno podkreśla wspólnotowy charakter życia ludzkiego. Zabieganie o interesy poszczególnych ludzi czy grup ludzkich musiało zaowocować tak wyraźnym podkreśleniem w Katechizmie nie tylko godności każdego człowieka jako osoby oraz jej integralnego, a więc i nadprzyrodzonego powołania, ale także jej powołania do wspólnoty.

Znamienną rzeczą jest, że Katechizm tak mocno podkreśla potrzebę życia społecznego ${ }^{33}$. Co więcej, formułuje on również podstawowe zasady tego życia. Wbrew skrajnie socjologicznym ujęciom społeczności redaktorzy Katechizmu wskazują na jej najgłębszy fundament w stwórczym akcie Boga. Określając zaś zasady jej funkcjonowania, zwracają uwagę nade wszystko na miłość, ale także na prawdę, sprawiedliwość, wolność, bez których życie we wspólnocie nie byłoby możliwe. Także bardziej szczegółowe określenie relacji między osobą a społecznością poprzez zasady solidarności, dobra wspólnego, pomocniczości wskazuje na pewien kontrast, jaki istnieje między obecną sytuacją a ideałem, do którego należy dążyć. Trudno oprzeć się wrażeniu, że to podkreślenie społecznego charakteru życia ludzkiego jest odpowiedzią na ujęcia skrajnie indywidualistyczne. Jest to z pewnością także jasne wskazanie dla refleksji teologicznomoralnej, która w przeszłości przesadnie koncentrowała się na człowieku

${ }^{32}$ Por. S. Nowosad, Wspólnotowy wymiar życia chrześcijańskiego, s. 62.

${ }^{33}$ Por. KKK, nr 1879; J. Römelt, Indyvidualethik oder Sozialethik? Der neue Katechismus der Katholischen Kirche zwischen Sozial-theologie, Kritik der bürgerlich-säkularischen Geschellschaft und theologisch-personalistischer Abstraktion, "Studia Moralia” 32 (1994) nr 1, s. 137. 
jako ,jednostce przed Bogiem zatroskanej o zbawienie własnej duszy"34, a pomijała albo ograniczała do minimum aspekty społeczne. Teraz, nie pomijając wymiaru indywidualnego, winna ona wyraźniej uwzględniać relacje międzyosobowe. Można więc stwierdzić, że Katechizm, dowartościowując wymiar wspólnotowy, odnosi się pośrednio do tendencji skrajnie liberalnych w życiu społecznym oraz do wyrastających ze średniowiecznego nominalizmu indywidualistycznych ujęć teologii moralnej. Nie oznacza to, że Katechizm nie docenia indywidualnego wymiaru życia człowieka. Redaktorzy mają z pewnością świadomość, że także w dzisiejszym świecie istnieją totalitarne i skrajnie kolektywistyczne modele życia społecznego. To do nich przede wszystkim skierowana jest zasada, że „osoba ludzka jest i powinna być zasadą, podmiotem i celem wszystkich urządzeń społecznych"35.

Nie ulega wątpliwości, że sytuacja współczesnego świata może stać się dla wielu chrześcijan swoistą pokusą, by zamknąć się w wąskim kręgu osobistej religijności i kultu; by wycofać się z życia społecznego, które zdaje się sprzeciwiać prawdzie Ewangelii. Katechizm nie pozostawia w tym względzie żadnych wątpliwości. Życie chrześcijańskie w żadnym wypadku nie może oznaczać ucieczki od świata. Przeciwnie, ma być ono świadectwem wiary, nadziei i miłości; ma być kontynuacją dzieła stworzenia oraz współpracą w dziele zbawczym Chrystusa. Ma ono prowadzić do budowania powszechnego braterstwa między ludźmi w Chrystusie. Dlatego na kanwie przykazań z tzw. drugiej tablicy Dekalogu zostały przypomniane podstawowe obowiązki w tym względzie. I tak, według Katechizmu, czwarte przykazanie, oprócz swojej tradycyjnej treści, obejmuje także problem stosunku Kościoła do wspólnoty politycznej. Interpretacja przykazania piątego koncentruje się wokół zagadnienia wartości życia i obowiązku jego poszanowania od momentu poczęcia wraz z takimi zagadnieniami szczegółowymi, jak: używanie narkotyków, eksperymenty dokonywane na człowieku czy handel bronią. W ramach szeroko rozbudowanego przykazania szóstego omawia się problem konieczności uznania własnej płciowości, powołania mężczyzny i kobiety do wzajemnej komunii miłości, dobro małżeństwa i rodziny, problem regulacji poczęć, techniki sztucznego zapłodnienia i zastępczego macierzyństwa. Jest to zatem pozytywny wykład nauki Kościoła, nastawiony - jak się wydaje

${ }^{34}$ Por. F. Greniuk, Katolicka teologia moralna w poszukiwaniu własnej tożsamości, Lublin 1993, s. 178.

${ }^{35}$ KDK, nr 25; KKK, nr 1881. 
- na kształtowanie pewnej wizji płciowości w dobie wielu wypaczeń tej dziedziny ludzkiego życia. W ramach przykazania siódmego został poruszony problem integralności dzieła stworzenia, panowania człowieka nad naturą oraz zasady społecznego nauczania Kościoła; w tym także konieczność międzynarodowej solidarności przy rozwiązywaniu palących problemów rodziny ludzkiej. Jak widać, poszczególne przykazania Dekalogu są wystarczająco pojemne, by zmieścić w nich problematykę, którą przyniosły dopiero nasze czasy.

Katechizm, przypominając "starą" prawdę Dekalogu, zdaje się bronić tych praw człowieka, które we współczesnym świecie zostały poddane niedopuszczalnym uzurpacjom ze strony społeczeństwa i państwa $^{36}$. Dotyczy to prawa do życia, do własności, do prawdy, ale także praw rodziny. Dlatego oprócz oceny "starych" zamachów na życie dużo miejsca poświęca aborcji, eutanazji, a więc zjawiskom, które we współczesnych społeczeństwach zyskują coraz większą akceptację. Znajdują się tu również zjawiska zupełnie nowe, jak: nadużywanie pokarmu, alkoholu, narkotyków, nikotyny, lekarstw, a nawet przekraczanie dozwolonej prędkości w prowadzeniu środków lokomocji. Do tych nowych zjawisk należą także coraz większe możliwości w zakresie eksperymentów medycznych i transplantacji ludzkich organów. "Nowość” nauczania moralnego w Katechizmie polega zatem nie tylko na głębszym, niż miało to miejsce dotychczas, uwzględnieniu zagadnień społecznych, ale także na zwróceniu uwagi na społeczny wymiar problemów, które tradycyjnie wchodziły w zakres etyki indywidualnej ${ }^{37}$.

Katechizm przypomina, że Kościół winien mieć zawsze i wszędzie prawdziwą swobodę $w$ głoszeniu wiary, a także $w$ wydawaniu oceny moralnej nawet $\mathrm{w}$ kwestiach dotyczących spraw politycznych, kiedy domagają się tego podstawowe prawa osoby lub zbawienia dusz, stosując wszystkie i wyłącznie te środki, które zgodne są z Ewangelią i dobrem powszechnym według różnorodności czasu i warunków ${ }^{38}$. Wydaje się, że Katechizm sam ten postulat realizuje. Odrzucając pewne ideologie, ukazuje jednocześnie podstawowe wyznaczniki, kryteria i wartości, na jakich winno opierać się $\mathrm{w}$ pełni ludzkie funkcjonowanie społeczności. Wiele problemów w Katechizmie jest jedynie zaznaczonych. Niektóre z nich są

${ }^{36}$ Por. S. Mojek, Będziesz mitowat bliźniego swego... II tablica Dekalogu, w: Katechizm Kościoła Katolickiego. Przestanie moralne Kościoła, s. 115.

${ }^{37}$ Por. A. Szostek, Etyka otwarta na Ewangelię, s. 174.

${ }^{38}$ Por. KKK, nr 2246. 
wręcz ukryte. Nie ulega jednak wątpliwości, że można mówić o postępie nauki o moralności w Katechizmie. Postęp ten jednak nie polega - jak mogłoby się wydawać - na osłabieniu obowiązywalności przynajmniej niektórych norm, ale na głębszym rozumieniu godności człowieka i tego, co z niej wynika. Przesłanie wynikające z tej godności i jej zobowiązującego charakteru Kościół pragnie głosić współczesnemu społeczeństwu. Czyni to $\mathrm{w}$ duchu dialogu, a więc przedstawia swoje racje i swoje rozumienie spraw, a jednocześnie wsłuchuje się w to, co ma mu do powiedzenia dzisiejszy świat. To przesłanie świata nie jest jednolite, ponieważ i sam świat ma charakter pluralistyczny. Dlatego także sam dialog jest niesłychanie trudny, ponieważ trudno zidentyfikować jego partnera, a już zidentyfikowany partner ten zmienia swoje pozy i role. Kościół jednak, wypełniając swoją misję, będącą odpowiedzią na wezwanie Chrystusa: „Idźcie więc i nauczajcie wszystkie narody (Mt 28,19) oraz „Idźcie na cały świat i głoście Ewangelię wszelkiemu stworzeniu (Mk 16, 15), wyraża gotowość do takiego dialogu, będącego zaprzeczeniem $\mathrm{z}$ jednej strony religijnej hermetyczności, a $\mathrm{z}$ drugiej religijnego fundamentalizmu $\mathrm{u}^{39}$.

Trudno zgodzić się z twierdzeniem, że „Redaktorzy Katechizmu - zapewne celowo - nie uwzględnili całego zapośredniczenia chrześcijańskiego, a więc pełnej relacji do świata, do historii, kultury, nauki, ekologii, do życia socjalnego, politycznego i ekonomicznego, słowem: została pominięta niemal cała "teologia świata»"40. Być może rzeczywiście wiele szczegółowych problemów nie zostało wprost wypowiedzianych czy szczegółowo opisanych, jednakże - jak się wydaje - to właśnie zmieniające się warunki życia współczesnego człowieka, narastające problemy społeczne stały się fundamentem dla takiego, a nie innego ujęcia problematyki. Fundament ma to do siebie, że nie zawsze jest widoczny. Podobnie nauczanie Katechizmu zdaje się być odpowiedzią na pewne tendencje, które nie zawsze zostały nazwane po imieniu. Jednakże z charakteru tego nauczania wynika, że jest ono stanowiskiem „wobec”, odniesieniem "do” określonej rzeczywistości. Posiada zatem wyraźny rys kairologiczny, który musi być wskazówką dla współczesnej teologii moralnej uprawianej w duchu Soboru Watykańskiego II.

${ }^{39}$ Por. J. Szymik, Chrześcijaństwo otwarte, s. 240.

${ }^{40}$ Taką opinię wyraża S. Bartnik, Wartość chrześcijaństwa, w: Katechizm Kościota Katolickiego. Wprowadzenie, s. 277. 
$* * *$

Jeszcze przed opublikowaniem Katechizmu niektórzy teologowie wyrażali obawy, że u podstaw takiego opracowania leży wiara $\mathrm{w}$ istnienie takiej prawdy teologicznej i moralnej, która odrzuca jej uzależnienie od uwarunkowań historycznych i kulturowych ${ }^{41}$. Jak się jednak okazało, obawy te były całkowicie nieuzasadnione. Katechizm Jana Pawła II, jak żaden dotychczasowy, uwzględnił perspektywę historyczną i kulturową. Aktualna sytuacja niewątpliwie wywarła duży wpływ na sposób przedstawienia i próbę wyjaśnienia problemów. Być może to właśnie chęć jak najpełniejszego przedstawienia współczesnych problemów sprawiła, że część Katechizmu dotycząca życia moralnego, przynajmniej w niektórych fragmentach, zyskała charakter swoiście kazuistyczny. W ogólne ramy Bożych Przykazań zostały włączone konkretne problemy, niekiedy bardzo złożone, skomplikowane; o wiele bardziej niż w dawnych czasach. Oczywiście, trudno się spodziewać, by Katechizm odniósł się do absolutnie wszystkich problemów moralnych współczesności. Odwołanie się do zasad ogólnych daje jednak możliwość oceny tych problemów, które pojawiły się już po opublikowaniu Katechizmu, jak też tych, które mogą pojawić się w bliższej lub dalszej przyszłości. Mimo że, jak twierdzą niektórzy, struktura Katechizmu okazała się jakby za wąska dla prezentacji przynajmniej niektórych zagadnieńn ${ }^{42}$, to - jak się wydaje - pozwoliła ona w wystarczającym stopniu odnieść się do współczesnych zjawisk, typowych tendencji. Znakiem tego jest, paradoksalnie, nierównomierne rozłożenie akcentów $\mathrm{w}$ omawianiu poszczególnych zagadnień. Jedne z nich Katechizm wyraźnie eksponuje, inne zostają zaledwie wspomniane. Wydaje się w związku z tym, że nie będzie nadużyciem stwierdzenie, że także ilość poświęconego miejsca świadczy o szczególnej aktualności problemu i jego wadze we współczesnej kulturze. Z perspektywy dwudziestu lat, jakie upłynęły od ogłoszenia Katechizmu, należy stwierdzić, że wpisał się on w dialog, jaki Kościół prowadzi ze współczesną kulturą. Ponieważ jednak przemiany kulturowe dokonują się bardzo szybko, wierność duchowi Katechizmu oznacza konieczność ciągłej ich analizy, przez co refleksja teologicznomoralna zachowa swój podstawowy rys, jakim jest jej kairologiczny charakter.

${ }^{41}$ Takie tezy zgłaszali m.in. J. B. Metz, E. Schillebeeckx.

${ }^{42}$ Por. J. Nagórny, Moralność życia społecznego w ujęciu Katechizmu Kościoła Katolickiego, w: Katechizm Kościoła Katolickiego. Przestanie moralne Kościoła, s. 173. 
Streszczenie. Zadaniem każdego katechizmu jest przedstawić wiarę w sposób jasny i komplementarny, przy zastosowaniu zrozumiałego w danym czasie i kulturze dla wszystkich języka. T reść ta musi wejść w pewien rodzaj dialogu ze współczesnym człowiekiem jak i kulturą, aby efektywnie służyć i przynosić owoce wiary i życia moralnego. Taka sama prawda dotyczy Katechizmu Kościoła Katolickiego ogłoszonego przez Jana Pawła II, który ma swoje oparcie także we współczesnej kulturze. Można je dostrzec zarówno w celach, środkach, jak i sposobach prezentacji depozytu wiary. Zamaiarem redaktorów było ukazać nauczanie Magisterium w możliwie najbardziej przystępny sposób. Metodą nie jest potępianie błędów doby współczesnej, zgodnie z apologetyką, ale przedstawianie prawd wiary i moralności w najbardziej pozytywny sposób, biorąc pod uwagę specyfikę adresata, będącego pod wpływem wielu różnych prądów i tendencji, które niekoniecznie są pr zyjazne wierze i życiu na niej opartemu. Jest rzeczą wiadomą, że obecna sytuacja ma wpływ na sposób prezentacji problemów w Katechizmie. Kulturowe podstawy mogą zostać dostrzeżone tam, gdzie bierze się pod uwagę postęp antropologiczny, wiedzę techniczną jak i zmiany społeczne uznane za wyzwanie. Można je zauważyć, gdy nowe rzeczy są poruszane, i gdzie stare rzeczy są interpretowane w nowy sposób. Katechizm nie dedykuje żadnej ze swych części wyłącznie zagadnieniom kultury współczesnej, chociaż wyraża jej stosunek do współczesnych religii, nauki, prądów filozoficznych czy też systemów politycznych opisujących zarówno relację człowieka do Boga, jak i jego życie w społeczeństwie. Patrząc z perspektywy dwudziestu lat od dnia podpisania Katechizmu można powiedzieć, że stał się ważnym elementem dialogu kulturowego Kościoła. Z powodu szybkich zmian zachodzących w kulturze należy podkreślić znaczenie wierności duchowi Katechizmu, jednocześnie prowadzącej do nieustannych analiz i ciągłych adaptacji, nie w kontekście treści, ale $\mathrm{w}$ sposobie prezentacji wiary i zagadnień moralnych.

Słowa kluczowe: nauczanie moralne; kultura; katechizm; dialog; Dekalog.

Abstract. The moral teaching of the Catholic Church in the dialog with the modern culture. Any catechism's goal is to present faith in clear and complete way, using language understandable for common people of given time and culture. It has to enter a kind of dialog with modern man and his culture, to serve effectively and bring fruits in faith and moral life. The same is true to the Catechism of Catholic Church, announced by John Paul II. It also has its cultural foundations. One can see them both in goals and means alike, as well as ways of presentation of the deposit of faith. The editors goal was to present the Magisterial teaching in the most clear way. The method is not to condemn errors of present time, together with controversies and apologetics, but to present the truths of the faith and moral issues in the most positive way, knowing the specifics of the recipient, influenced by various cultural currents and tendencies, which are not very friendly to the faith and life built on it. Obviously, the present situation has its impact on the way the problems are presented in the Catechism. The cultural foundations can be recogni- 
zed, where anthropological progress, technical knowledge and social changes are taken into account, considered as challenges. One can see them where new issues are brought up, and where old ones are interpreted in a new way. The Catechism does not have any specific part focused on modern culture description, however it expresses its attitude toward present religions, sciences, philosophies or political systems describing both man's relationship with God, as well as his life in human society. Looking from the perspective of twenty years since the Catechism was signed, it can be said, that it became in important element of cultural dialog of the Church. Due to the rapid changes in the culture, the significance of faithfulness to the spirit of the Catechism must be recognized, in the same time leading to on-going analyses and constant adaptation, not in contents, but in manner of presentation of the faith and moral issues.

Keywords: Moral teaching; culture; Catechizm of the Catholic Church; dialogue; Decalogue. 